\title{
Responsibility and accountability in community mental health teams
}

\author{
Steve Onyett
}

\begin{abstract}
Community mental heatth teams are handicapped by long-standing amblgulties about responslbility and accountability. Protesstonal responsiblities need to be separated from practitioner's responsibulities as employees, and clear lines of accountability established accordingly. This requires stronger delegated operational management responstbility of feam lovel. Greater attention should bo paid to defining shared, core responstbilities anong tean practitioners employed by hectth and social services. These cre here defined as 'care coordinating' responsibilities and provide a means of reconcling the care programme approach and care management into coherent practice.
\end{abstract}

The Clunis report produced a damning indictment of ambiguous definition and allocation of responsibilities within mental health services (Ritchie et ah, 1994). Its recommendations and subsequent government guidance (NHSME, 1994a,b) left unresolved important questions of accountability and responsibility among practitioners working within multidisciplinary teams. These ambiguities are long-standing and contribute to ambivalence about multidisciplinary teams among professional practitioners (Galvin \& McCarthy, 1994). The aim here is to offer definition of the important responsibilities to be allocated and managed within teams, and recommendations for the allocation of these responsibilities by employing authorities.

\section{Responsibility and accountability}

The terms 'responsibility' and 'accountability' are often used interchangeably. Responsibility is here defined as a set of tasks that an employing authority, professional body or court of law can legitimately demand of a practitioner. Accountability describes the relationship between that practitioner and the authority.

Professional practitioners within teams are accountable for different responsibilities to different authorities. They have employee responsibilities that are defined by their contract of employment and general management. They also have professional responsibilities defined by a duty of care to their patients, professional codes of conduct. and in some cases, state registration requirements. For staff in training or recently qualified (e.g. two years post-qualification for psychologists) this includes formal accountability to a professional line manager in a clinical supervisory role. Professional responsibility also encompasses a legal responsibility on professionals to recognise and observe the limits of their own training and competence, and satisfy themselves that anyone else to whom they refer is also appropriately qualified and competent. Professional responsibilities also include specific statutory responsibilities for responsible medical officers (RMOs) and social workers under the Mental Health Act.

It follows from the circumscribed nature of professional responsibility that no professional can be held accountable for another professional's actions except in part by negligent delegation or inappropriate referral (British Psychological Society, 1986). This resolves the unhelpful conflation of medical responsibility and ultimate clinical responsibility. Medical responsibility is best regarded as a particular instance of professional responsibility whereby practitioners are accountable for those tasks for which they are recognised as competent as a result of their medical training. Ultimate clinical responsibility is claimed by the senior medical member of the team when he/she 
asserts that he/she is accountable for the work of the team as a whole should disaster occur. The latter is unjustified. The Nodder Report concluded that there is "... no basis in law for the commonly expressed idea that a consultant may be held responsible for negligence on the part of others simply because he is the responsible medical officer'; or that, though personally blameless, he may be held accountable after the style of a military commander. A multidisciplinary team has no 'commander' in this sense" (DHSS, 1980). There has been no subsequent body of case law to substantially alter this conclusion.

\section{Responsibilities within teams serving people with severe and complez health and social care needs}

Case coordinating responsibility has been defined as "coordinating other team members who are serving the same client" as opposed to care management which goes beyond the team and entails accessing, coordinating and liaising with all the services needed for appropriate assessment, treatment and care (Ovretveit, 1993, p. 107). In practice, the need for continuous management of care when working with an individual with complex health and social care needs dictates that coordination of services within and outside the team should be done by the same person. Case coordination and care management should therefore be combined in the task of care coordination shown in Table 1.

\section{Integrating the care programme approach and care management through care coordination}

The health-led care programme approach (CPA) aims to improve coordination and continuity of care through systematic assessment, care planning and review, and the allocation of clear 'key-worker' responsibilities. Social services-led care management has the same aims and allocates similar responsibilities to a "care manager' with additional powers to purchase social care. Both key-workers and care managers are charged with ensuring that assessments of health and social care are carried out. Overlap between the care programme approach (CPA) and care management is also evident in the stated purposes for supervision registers (NHSME,
Table 1. Care coordinating responsibillties

Coordinating care within the feam ('case coordination')

Carrying out core assessments.

Ensuring that other team members contribute to a more comprehensive assessment as required.

Collecting and maintaining information from other involved workers in the team for continued monitoring and review.

\section{Coordinating care beyond the feam}

('care management')

Achieving appropriate input from other statutory and independent providers. This may include the use of a devolved (preferable joint health and social services) budget.

Monitoring the outcome of provision and feeding this back to team reviews. This will require regular and long-term contact with the service user themselves.

Ensuring that involved workers beyond the team are involved in team reviews and that the views of users, relatives and friends are represented. Collecting and maintaining information from others involved outside the team for continued monitoring and review.

1994a). These include providing a care plan that aims to reduce risk, regularly reviewing care needs, maintaining contact, providing a point of reference for relevant and authorised health and social services staff, planning for the facilities and resources necessary to meet need and identifying those patients who should recetve the highest priority for care, and active following-up. All these functions have been previously described as the remit of care management (Department of Health/ Social Services Inspectorate, 1991). The need to integrate CPA and care management has been given further impetus by fears that care management will marginalise the role of social workers in community mental health teams (CMHTs) or remove them altogether, and that GP fund-holding will have a fragmenting effect on the future pattern of services (Mental Health Act Commission, 1993; Morris \& Davidson, 1992).

Care management will only apply to those people with the most complex health and social care needs. These will be a subset of those subject to the CPA but are likely to include those on supervision registers. For these individuals there is a danger of duplication and poor coordination unless the task of ensuring the assessment, planning, monitoring and review of health and social 
care needs form a single role. These are the essential tasks of care coordination. The separate approval of health and social care funding should then take place at an organisational level that is superordinate to team members on the basis of their jointly agreed assessments. This demands effective joint health and social services commissioning and the development of appropriate joint management structures to allow equitable access to devolved budgets for the purchase of care by practitioners managed by both health and social services (Onyett, 1992). Such arrangements are in the spirit of earlier care management guidance which stated that while care management is a social services-led activity, care management itself could be undertaken by practitioners employed by other agencies (Department of Health, 1990).

It is encouraging that a recent Sainsbury Centre survey of CMHTs in England found that among teams operating case or care management, $86 \%$ considered case or care management as "one of a number of tasks of professional practitioners" (Onyett et al, 1994). Only 9.7\% reported that "staff responsible for case/care management [were] solely case/care managers". This suggests that CMHTs are attempting to integrate care management with existing practice rather than operating it as a parallel and possible duplicative activity. There are examples of the CPA and care management being regarded as synonymous for the most disabled clients (North \& Ritchie, 1993; Onyett \& Davenport, 1994).

Teams of health and social services staff with responsibility for care coordination will be similar to 'continuous care teams' that coordinate and, where necessary, provide care. These are being advocated in the US following the realisation that case management outside of multidisciplinary provider teams fails to bring together an effective package of care where resources are inadequate and agencies lack incentives to work together (Stein, 1992).

\section{The need for stronger operational management at team level}

It would be helpful if the term 'key-worker' could be reserved for staff doing case coordination within provider agencies that have no responsibility for the coordination of other services (e.g. hostel and day hospital staff). In this way managers with a multiagency remit to purchase and coordinate care could link with key-workers in those agencies. Unfortunately, recent guidance has reaffirmed the term 'key-worker' with respect to the CPA (NHSME, 1994b). Whatever the person with care coordinating responsibility is called, it is crucial that this responsibility is allocated, monitored and managed through a team process. This in turn requires that operational management responsibilities are clearly allocated at team level to either a team manager, a consultant psychiatrist or other senior practitioner, or other combinations of competent individuals. Management tasks should be clearly divided up (not shared) between them.

Responsibility for ensuring allocation of care coordinating responsibility is separate from deciding who that responsibility should be allocated to. Most practitioners would regard the assumption of the latter by consultant psychiatrists or others to whom operational management may be delegated as a retrograde step towards traditional institutional practice. Nonetheless, it is important that one person has ultimate responsibility for ensuring allocation of care coordinating responsibility for each individual service user. Subsequent to allocation this manager has to ensure that care coordination tasks are carried out. Care coordination thus becomes the core role for practitioners to which their profession-specific competencies are additions.

The Sainsbury Centre CMHT survey found a general abdication of management responsibilities (Onyett et al, 1994). For example, although $75 \%$ of the teams surveyed reported having a team manager or coordinator, only $20 \%$ of teams gave them most responsibility for allocating cases to team members. For $51 \%$ of CMHTs the team as a whole' had ultimate responsibility. The team's senior doctor had most responsibility in only $2 \%$ of teams.

The employing authority needs to fulfil its responsibility to develop and monitor realistic operational policies to ensure practitioners in teams are able to execute the responsibilities described above (see Table 2). Uppermost is the requirement that practitioners have every opportunity to exercise their professionspecific skdlls where appropriate. The consequences of fallure, refusal or negligence in the exercise of employee responsibilities is of a lower order than the consequences of a 
Table 2. Key agents in multidisciplinary teamworking, their responsibilities and lines of accountability

\begin{tabular}{|c|c|c|}
\hline Agent & Responelbuilties & Accountable to \\
\hline $\begin{array}{l}\text { General management in proper } \\
\text { consultation with practitioners }\end{array}$ & $\begin{array}{l}\text { Establishment and monltoring of systems for } \\
\text { proper exercise of responsibilities described } \\
\text { below }\end{array}$ & Trust boards/DMU \\
\hline $\begin{array}{l}\text { Team manager/other designated } \\
\text { team members }\end{array}$ & $\begin{array}{l}\text { Devolved management tasks (e.g. allocation, } \\
\text { coordinating leave) - an employee } \\
\text { responsibility }\end{array}$ & $\begin{array}{l}\text { General management/trust } \\
\text { board }\end{array}$ \\
\hline \multirow[t]{3}{*}{ Practtioners } & $\begin{array}{l}\text { Employee responsibilities such as care } \\
\text { coordination and compliance with } \\
\text { operational policy }\end{array}$ & $\begin{array}{l}\text { Team manager/other } \\
\text { designated team members }\end{array}$ \\
\hline & $\begin{array}{l}\text { Professional responsibilities (e.g. a CPN } \\
\text { administering medication, a psychiatrist's } \\
\text { RMO responsibilities and prescription of } \\
\text { medication, assessment of activities of daily } \\
\text { living by an occupational therapist) }\end{array}$ & $\begin{array}{l}\text { Professional line managers } \\
\text { and/or clinical supervisors } \\
\text { where training or recently } \\
\text { qualified }\end{array}$ \\
\hline & & $\begin{array}{l}\text { Otherwise to professional } \\
\text { bodies or courts of low }\end{array}$ \\
\hline
\end{tabular}

failure to exercise professional and legal responsibilities. The former can result in dismissal from a particular post but the latter can result in loss of professional status altogether and legal proceedings. It is therefore important that operational managers in defining employee responsibilities do not compromise opportunities to exercise professional and legal responsibilities appropriately.

While operational managers need to ensure that professional responsibility can be appropriately exercised, practitioners may want to be advised by peers from their own profession on the execution of these responsibilities, and junior or training staff must retain formal accountability to professional line managers. In the Early Intervention Service, an inner London CMHT, accountability for professional responsibility was to professional line managers (where required) while accountability for employee responsibilities was to a team coordinator. Although practitioners had little contact with professional line managers, this arrangement was nonetheless important in ensuring organisational clarity. This service achieved positive outcomes for service users in a controlled study (Merson et al, 1992), was positively evaluated by referrers (Onyett et al, 1990) and, unlike other demonstration projects (e.g. Audini et al, 1994), has maintained high morale and low staff turnover to-date.

Recent guidance and government reports (e.g. Mental Health Nursing Review Team, 1994) unambiguously highlight the need to prioritise people with severe and long-term mental health problems. In order to make the most effective use of available resources operational management responsibility will need to be effectively delegated to competent team members in order to ensure that care coordination is effectively exercised and monitored. Clear definition of care coordinating responsibilities may offer a delineation of joint working practices across health and social services and could in future form the basis of core multidisciplinary training for community care.

\section{Acknowledgements}

I am grateful to Drs Jamie Furnell and Matt Muijen for comments on an earlier draft of this paper.

\section{References}

Audin, B., Marks, I. M.. LaWrence, R. E., Connoluy, J. \& WATTS. V. (1994) Home-based versus out-patient/inpatient care for people with serious mental illness. Phase II of a controlled study. Brttish Journal of Psychiatry. 165. 204-210. 
BRTISH PSYchOLOGICAL SOCIETY (1986) Responstblity Issues in Clinical Psychology and Multidisclplinary Teamwork. Leicester: BPS.

Department OF Health \& SOCLA SECURTY (1980) Organisational and Management Problems of Mental Miness Hospitals. London: HMSO.

DEPARTMENT OF HEALTH (1990) Communtty Care in the Next Decade and Beyond. London: HMSO.

DEPARTMENT OF HEALTH/SOCIAL SERVICES INSPECTORATE (1991) Care Management and Assessment: managers guide. London: HMSO.

GaLVIN, S. W. \& MCCARTHY, S. (1994) Multi-disciplinary community teams: clinging to the wreakage. Journal of Mental Health, 3, 167-174.

Mental Health Nursing ReView TEam (1994) Working in Partnership. London: HMSO.

MEntal Health ACT Commission (1993) Fyth Biennial Report 1991-1993. London: HMSO.

MERSON, S., TYRER, P.. ONYETT, S., LACK, S. et al. (1992) Early intervention in psychiatric emergencies: a controlled clinical trial. Lancet, $389,1311-1314$.

MORRIS, D. \& DAVIDSON, L. (1992) Community mental health centres in a changing environment. Journal of Mental Health. 1, 295-299.

NHS MANAGEMENT ExEcutive (1994a) Introduction of Superviston Registers for Mentally III People from 1 Aprll 1994. HSG(94)5. HMSO.

- (1994b) Guidance on the Discharge of Mentally Disordered People and Their Continuing Care in the Community. HSG(94)27. HMSO.
NORTH, C. \& RTCHIE, J. (1993) Factors Influencing the Implementation of the Care Programme Approach. London: HMSO.

ONYETT, S. (1992) Case Management in Mental Health. London: Chapman \& Hall.

- \& DAVENPORT, S. (1994) Care programming and care management in Rochester. Community Care Management and Planning. 1, 116-123.

-. TYRER, P., ConNolly, J., MALONe, S. et al, (1990) The Early Intervention Service: the first 18 months of an inner London demonstration project. Psychiatric Bulletin, 14, 267-269.

-. Heppleston, T. \& Bushneu, D. (1994) A national survey of community mental health teams. Joumal of Mental Health, 8, 175-194.

OVRETVErT, J. (1993) Coordinating Community Care: multidisctplinary teams and care management. Buckingham: Open Untversity Press.

RrTCHIE. J., Dick, D. \& LINGHAM, R. (1994) Report of the Christopher Clunis Enquiry. London: HMSO.

STEIN, L. I. (1992) On the abolishment of the case manager. Health Affairs, Fan, 172-177.

Steve Onyett, Senior Research Fellow, Centre for Mental Health Services Development, Kings College London, Campden Hill Road, London W8 7AH

\title{
A nurse-led psychiatric intensive care unit
}

\author{
Roland Dix
}

\begin{abstract}
Sovern NHS Trust has recently commissioned a peychiatric Intensive care unit (PICU) which became operational on 18 July 1994. Although the number of PICUs is Increasing and their services are greatty valued, they are ofien fraught with problems. A model for the development of PICU services is described. It includes admission crtteria, overall clinical organisation of the PICU, discharge criteria and a discussion. The model described is based on the hypothesis that the primary role of the PICU is to deal with clinical nursing problems rather than medical problems. The discusston points out some of the instrumental components necessary for the successful development of PICU services.
\end{abstract}

Since the demise of locked acute wards in the early '70s, many general adult in-patient services have identified a need for a ward which can provide a higher level of nursing intervention (Glancy, 1975). Such a unit should also be able to deal effectively with problematic behaviours that often result from the acute phase of mental illness (Tarbuck, 1994). The Reed report (1992) recommends 40 psychiatric intensive care unit (PICU) beds per million population. The PICU is now a well established part of many adult mental health provisions. 